\title{
Iron Intake, Hemoglobin Level, and Red Blood Cell Indices in Adolescents with Obesity
}

\author{
Aviyani $^{*}$, Ginna Megawati**, Susi Susannah ${ }^{* * * *}$ \\ * Faculty of MedicinePadjadjaran University- Hasan Sadikin Hospital \\ ${ }^{* *}$ Department of Public Health Faculty of MedicinePadjadjaran \\ University- Hasan Sadikin Hospital \\ *** Department of Pediatrics Faculty of MedicinePadjadjaran \\ University- Hasan Sadikin Hospital \\ Jl. Pasteur 38, Bandung 40161,Indonesia \\ Email: aviyanivivi@hotmail.com
}

\begin{abstract}
Obesity is a condition of excess and abnormal fat accumulation. Obese adolescents are at greater risk of developing iron deficiency anemia with microcytic hypochromic red blood cells $(R B C)$. Iron deficiency in obesity relates to low iron intake, abnormal iron absorption, and increased iron utilization. The aim of this study was to determine iron intake, hemoglobin level, and RBC indices in faculty of medicine students with obesity. We used descriptive crosssectional method, involving year of 2016 students in Faculty of Medicine Padjadjaran University with obesity. Pregnant women and students with previous history of thallasemia or anemia were excluded. Iron intake was assessed using Food Frequency Questionnaire. Hemoglobin level and RBC indices were measured in Hasan Sadikin General Hospital. Iron intake of male subjects were adequate in $62,5 \%$ subjects and low in $37,5 \%$ subjects. Iron intake in female subjects were adequate in $20 \%$ subjects and low in $80 \%$ subjects. Male hemoglobin level were normal and $20 \%$ of female subjects had anemia. All male subjects were normochrom normocytic, $40 \%$ female subjects were hypochrom microcytic.
\end{abstract}

Keywords: adolescents, hemoglobin level, iron intake, obesity, red blood cell indices 


\title{
Gambaran Asupan Besi, Kadar Hemoglobin, dan Indeks Sel Darah Merah pada Remaja Obesitas
}

\author{
Aviyani", Ginna Megawati**, Susi Susannah $^{* * * *}$ \\ * Fakultas Kedokteran Universitas Padjadjaran / RSUP. Dr. HasanSadikin Bandung \\ ** Departmen Ilmu Kesehatan Masyarakat Fakultas Kedokteran, Universitas \\ Padjadjaran/RSUP Dr. Hasan Sadikin, Bandung \\ *** Departmen Ilmu Kesehatan Anak Fakultas Kedokteran, Universitas \\ Padjadjaran/RSUP Dr. Hasan Sadikin, Bandung \\ Jl. Pasteur 38, Bandung 40161,Indonesia \\ Email: aviyanivivi@hotmail.com
}

\begin{abstract}
Abstrak
Obesitas didefinisikan sebagai akumulasi lemak berlebihan dan abnormal. Remaja obesitas memiliki risiko anemia karena defisiensi besi yang ditandai dengan indeks sel darah merah mikrositik hipokrom. Penyebab defisiensi besi adalah rendahnya asupan besi, gangguan penyerapan besi, dan kebutuhan besi yang meningkat pada remaja obesitas. Tujuan penelitian ini adalah membahas gambaran asupan besi, kadar hemoglobin, dan indeks sel darah merah pada remaja obesitas yang merupakan mahasiswa kedokteran. Penelitian ini menggunakan metode deskriptif potong lintang. Penelitian melibatkan mahasiswa Fakultas Kedokteran Universitas Padjadjaran angkatan 2016 dengan obesitas. Kriteria eksklusi adalah mahasiswa yang sedang hamil dan memiliki riwayat penyakit talasemia atau anemia.Subjek mengisi Food Frequency Questionnaire untuk mengukur asupan besi.Kadar hemoglobin dan indeks sel darah merah diperiksa di Laboratorium Rumah Sakit Hasan Sadikin.Asupan besi pada subjek laki-laki $62,5 \%$ terkategori cukup dan 37,5\% terkategori kurang. Asupan besi pada subjek wanita $20 \%$ terkategori cukup dan $80 \%$ terkategori kurang. Kadar hemoglobin subjek pria normal dan $20 \%$ subjek wanita mengalami anemia. Semua subjek pria memiliki indeks sel darah merah normal yaitu normositik normokrom. Pada wanita, 40\% subjek memiliki indeks sel darah merah mikrositik hipokrom.
\end{abstract}

Kata kunci: Asupan besi, indeks sel darah merah, kadar hemoglobin, remaja obesitas 


\section{Research Article}

\section{Pendahuluan}

Obesitas didefinisikan sebagai akumulasi lemak berlebihan dan abnormal yang dapat mengganggu kesehatan. ${ }^{1}$ World Health Organization menyatakan bahwa obesitas merupakan suatu epidemik global dan menjadi masalah kesehatan yang harus segera ditangani. ${ }^{2}$ Salah satu kelompok yang rentan mengalami obesitas adalah kalangan remaja. Gaya hidup remaja seperti melewatkan sarapan, mengkonsumsi makanan cepat saji, serta cenderung sedentary life style, membuat remaja berisiko mengalami obesitas. ${ }^{3}$ Prevalensi obesitas di Indonesia sendiri pada kelompok umur 16-18 tahun sebesar 1,6\%. ${ }^{4}$ Remaja obesitas memiliki risiko anemia karena defisiensi besi. ${ }^{5}$

Anemia yang berarti penurunan kadar hemoglobin atau sel darah merah memiliki macammacam penyebab. Penyebab terbesar anemia adalah anemia defisiensi besi. ${ }^{6}$. Anemia defisiensi besi memiliki penampakan sel darah merah yang kecil (mikrositik) dan pucat (hipokrom). ${ }^{7}$ Sebanyak 38,8\% remaja obesitas memiliki kadar besi yang rendah dibandingkan dengan remaja normal yang prevalensinya 4,4\%. ${ }^{8}$ Penyebab defisiensi besi pada remaja obesitas adalah karena cenderung mengkonsumsi makanan tidak seimbang yang hanya kaya karbohidrat dan lemak. ${ }^{5}$ Peningkatan jaringan tubuh pada remaja obesitas juga membuat kebutuhan besi meningkat, sehingga semakin meningkatkan risiko terjadinya anemia. ${ }^{9}$ Selain itu, obesitas berkaitan dengan low-grade inflammation yang menganggu penyerapan besi di duodenum. ${ }^{10}$

Rendahnya asupan besi dapat dipengaruhi pola makan yang buruk. Pola makan yang buruk merupakan salah satu masalah yang dihadapi remaja terutama remaja yang baru memasuki kehidupan perkuliahan. Stres dan kurang waktu menjadi pemicu utama pola makan yang buruk. Hal ini menyebabkan kebutuhan nutrisi pada remaja menjadi tidak terpenuhi. ${ }^{8,} 11$ Mahasiswa kedokteran memiliki pengetahuan yang cukup akan kesehatan, namun karena stres dan kehidupan kedokteran yang berat membuat pola makan mereka menjadi tidak sehat. ${ }^{12,13}$

Berdasarkan uraian di atas, peneliti tertarik untuk meneliti asupan besi, kadar hemoglobin, dan indeks sel darah merah mahasiswa kedokteran dengan obesitas. Hal ini penting karena anemia dapat mengakibatkan dampak negatif bagi penderitanya seperti lekas lelah, konsentrasi belajar menurun, dan menurunkan produktivitas kerja. ${ }^{14}$

\section{Metode}

Penelitian ini merupakan penelitian deskriptif dengan pendekatan studi potong lintang. Penelitian dilakukan pada periode bulan April-Mei 2017 dan telah mendapatkan persetujuan etik nomor 458/UN6.C.10/PN/2017 yang dikeluarkan oleh Komite Etik Penelitian Kesehatan Fakultas Kedokteran Universitas Padjadjaran. 


\section{Research Article}

Kriteria inklusi dalam penelitian ini adalah mahasiswa Fakultas Kedokteran Universitas Padjadjaran angkatan 2016 yang obesitas berdasarkan WHO growth reference 5-19 years yaitu lebih besar dari 2 standar deviasi di atas median. Usia maksimal subjek adalah 19 tahun dan penentuan umur dilakukan berdasarkan ulang tahun terakhir. Mahasiswa yang tidak bersedia mengikuti penelitian, sedang mengandung, dan memiliki riwayat penyakit talasemia atau anemia berdasarkan anamnesis, tidak diikutsertakan dalam penelitian ini. Dari sebanyak 258 orang angkatan 2016, subjek yang memenuhi kriteria seleksi adalah sebanyak 19 subjek dengan 13 subjek yang bersedia mengikuti penelitian. Enam subjek tidak bersedia mengikuti penelitian karena tidak bersedia diambil darah.

Data penelitian adalah data primer berupa pengukuran asupan besi, kadar hemoglobin, dan indeks sel darah merah. Pengukuran asupan besi adalah asupan total zat besi subjek per hari, yang dibandingkan dengan Angka Kecukupan Gizi ${ }^{15}$ selanjutnya dikategorikan menjadi kurang atau cukup. Pengukuran asupan besi dilakukan dengan meminta subjek untuk mengisi formulir Food Frequency Questionnaire semikuantitatif. ${ }^{16}$ Daftar makanan yang ada di dalam formulir Food Frequency Questionnaire diambil dari Food Composition Tabel Indonesia dan kemudian dilakukan uji reliabilitas kepada 10 subjek awal dari populasi lain untuk melihat cukup atau tidaknya daftar makanan. Alat penunjang lain yang digunakan adalah Daftar Penukar Bahan Makanan dari Instalasi Gizi Rumah Sakit Hasan Sadikin Bandung untuk menyetarakan berat bahan makanan yang dipergunakan dalam ukuran rumah tangga ke dalam ukuran gram. Food Composition Tabel Indonesia juga dipakai untuk menghitung besar miligram besi dalam makanan.

Kadar hemoglobin dan indeks sel darah merah diperiksa di Instalasi Laboratorium Patologi Klinik Rumah Sakit Hasan Sadikin Bandung. Kadar hemoglobin adalah banyaknya hemoglobin per volume darah. Hasilnya akan diklasifikasikan menjadi hemoglobin normal dan rendah (anemia). Indeks sel darah merah diukur dengan MCV (Mean Cell Volume), MCH (Mean Cell Hemoglobin), dan MCHC (Mean Cell Hemoglobin Concentration). MCV merupakan estimasi rata-rata ukuran dari sel darah merah.Jika $M C V$ dalam batas normal, sel darah merah bersifat normositik; jika kurang dari normal, mikrositik; dan jika lebih besar dari normal, makrositik. $M C H$ dan $M C H C$ untuk menentukan kadar hemoglobin dalam sel darah merah. Jika dalam batas normal, sel darah merah bersifat normokromik; jika kurang dari normal, hipokromik; dan tidak ada sel darah merah yang bersifat hiperkromik. Selanjutnya, sel darah merah akan dikategorikan menjadi normositik normokrom, mikrositik hipokrom, dan makrositik normokrom. ${ }^{17}$

Data deskriptif disajikan dalam tabel untuk menggambarkan karakteristik. Pengolahan data dilakukan dengan menggunakan perangkat lunak statistika. 


\section{Research Article}

\section{Hasil}

Tabel 1 menunjukkan asupan besi subjek penelitian. Asupan besi subjek pria sebagian besar $(62,5 \%)$ termasuk ke dalam kategori cukup sementara asupan besi subjek wanita sebagian besar $(80 \%)$ masuk ke dalam kategori kurang.

Tabel 1 Gambaran Asupan Besi Subjek Penelitian

\begin{tabular}{ccccc}
\hline & Pria & & & Wanita \\
Asupan besi & n & \% & 4 & n \\
\hline Kurang & 3 & 37,5 & 1 & 80 \\
Cukup & 5 & 62,5 & 5 & 20 \\
\hline Total & 8 & 100 & 100 \\
\hline
\end{tabular}

Tabel 2 menunjukkan kadar hemoglobin subjek penelitian. Semua subjek pria memiliki kadar hemoglobin normal. Sebanyak 20\% dari subjek wanita mengalami anemia.

Tabel 2Gambaran Kadar Hemoglobin Subjek Penelitian

\begin{tabular}{|c|c|c|c|c|}
\hline \multirow[b]{2}{*}{ Kadar hemoglobin } & \multicolumn{2}{|c|}{ Pria } & \multicolumn{2}{|c|}{ Wanita } \\
\hline & $\mathbf{n}$ & $\%$ & $\mathbf{n}$ & $\%$ \\
\hline Normal & 8 & 100 & 4 & 80 \\
\hline Anemia & 0 & 0 & 1 & 20 \\
\hline Total & 8 & 100 & 5 & 100 \\
\hline
\end{tabular}

Tabel 3 menunjukkan gambaran indeks sel darah merah subjek penelitian. Semua subjek pria memiliki indeks sel darah merah normal yaitu normositik normokrom. Pada subjek wanita, 40\% subjek memiliki indeks sel darah merah mikrositik hipokrom.

Tabel 3Gambaran Indeks Sel Darah Merah Subjek Penelitian

\begin{tabular}{|c|c|c|c|c|}
\hline \multirow[b]{2}{*}{ Indeks sel darah merah } & \multicolumn{2}{|c|}{ Pria } & \multicolumn{2}{|c|}{ Wanita } \\
\hline & $\mathbf{n}$ & $\%$ & $\mathbf{n}$ & $\%$ \\
\hline $\begin{array}{c}\text { Normositik normokrom } \\
(M C V \text { normal } ; M C H \text { dan } M C H C \text { normal })\end{array}$ & 8 & 100 & 3 & 60 \\
\hline $\begin{array}{c}\text { Mikrositik hipokrom } \\
(M C V<; M C H \text { dan } M C H C<)\end{array}$ & 0 & 0 & 2 & 40 \\
\hline $\begin{array}{c}\text { Makrositik normokrom } \\
(M C V>; M C H \text { dan } M C H C \text { normal })\end{array}$ & 0 & 0 & 0 & 0 \\
\hline $\begin{array}{c}\text { Total } \\
\end{array}$ & 8 & 100 & 5 & 100 \\
\hline
\end{tabular}

\section{Diskusi}

Salah satu penyebab remaja obesitas berisiko mengalami anemia defisiensi besi adalah karena kurangnya asupan besi. ${ }^{5}$ Asupan besi $37,5 \%$ subjek pria dan $80 \%$ subjek wanita dalam 


\section{Research Article}

penelitian ini masih tergolong kurang dibandingkan dengan Angka Kecukupan Gizi ${ }^{15}$ yaitu 13 $\mathrm{mg} /$ hari untuk pria dan $26 \mathrm{mg} /$ hari untuk wanita. Remaja obesitas cenderung mengkonsumsi makanan tidak seimbang dan hal ini meningkatkan risiko anemia karena defisiensi besi. ${ }^{5}$ Wanita membutuhkan besi lebih banyak salah satunya karena efek kumulatif menstruasi. ${ }^{18}$ Simpanan besi yang ada di dalam tubuh digunakan setiap kali mengalami menstruasi. ${ }^{19}$ Pada penelitian ini, $80 \%$ wanita masih mengkonsumsi besi dalam kategori kurang yang semakin meningkatkan risiko anemia defisiensi besi di samping efek kumulatif menstruasi. ${ }^{18}$

Sebanyak satu subjek wanita dari 13 remaja obesitas dalam penelitian ini memiliki kadar hemoglobin rendah dan masuk ke dalam kategori anemia sedang mikrositik hipokrom. Selain itu, terdapat satu subjek wanita dengan kadar hemoglobin normal namun memiliki indeks sel darah merah mikrositik hipokrom. Tahap pertama dari anemia defisiensi besi adalah iron depletion. Pada tahap ini, tubuh yang kekurangan besi akan memecah cadangan besi yang ada sehingga belum terjadi gangguan pada pembentukan sel darah merah. Ketika cadangan besi sudah menurun, tubuh akan masuk ke dalam tahap iron-deficient erythropoiesis. Pada tahap ini, belum terjadi anemia namun pembentukan hemoglobin pada sel darah merah sudah mulai terganggu yang ditandai dengan penampakan sel darah merah yang kecil (mikrositik) karena ada gangguan pembentukan struktur hemoglobin dan pucat (hipokrom) karena hemoglobin yang diproduksi sedikit. ${ }^{7}$ Satu subjek penelitian wanita memiliki penampakan sel darah merah mikrositik hipokrom tetapi belum masuk ke dalam kategori anemia. Ketika defisiensi besi ini terus berlanjut, anemia defisiensi besi akan terjadi. ${ }^{7}$ Penelitian Murray-Kolb et al menyatakan bahwa wanita lebih berisiko mengalami defisiensi besi dan anemia defisiensi besi. ${ }^{18}$ Selain karena defisiensi besi, hal yang menyebabkan sel darah merah menjadi mikrositik hipokrom adalah talasemia dan anemia sideroblastik. ${ }^{20}$

Remaja obesitas berisiko mengalami anemia defisiensi besi karena kurangnya asupan besi $^{5}$ dan meningkatnya kebutuhan besi. ${ }^{9}$ Obesitas juga berkaitandengan low-grade inflammation. Sel lemak berlebihan pada orang obesitas, memicu dihasilkannya sitokin seperti IL-1 dan IL-6 yang menyebabkan inflamasi. Inflamasi menganggu penyerapan besi di duodenum karena menyebabkan ekspresi duodenal ferroportin yang rendah bersamaan dengan kenaikan konsentrasi hepcidin. ${ }^{10}$ Duodenal ferroportin berfungsi untuk transfer besi dari sel duodenum ke plasma sementara hormon hepcidin yang dihasilkan hati berfungsi untuk regulasi besi dalam darah. Ikatan hepcidin pada ferroportin akan menyebabkan proteolisis ferroportin, menurunkan transpor besi ke plasma, dan menjadi faktor defisiensi besi. ${ }^{21}$ Dalam penelitian ini, satu dari 13 subjek mengalami anemia. Kemungkinan, tubuh masih dapat mengkompensasi gangguan penyerapan besi yang diakibatkan inflamasi pada remaja obesitas dengan simpanan besi yang ada di dalam tubuh. ${ }^{21}$ 


\section{Research Article}

Penelitian di Meksiko tahun 2011 menyatakan bahwa risiko defisiensi besi pada remaja wanita obesitas adalah 2-4 kali lebih besar daripada individu dengan asupan besi serupa. Meningkatnya risiko defisiensi besi disebabkan karena efek inflamasi obesitas pada absorpsi besi yang dikonsumsi. ${ }^{22}$ Penelitian serupa di Amerika juga menyatakan bahwa subjek dengan obesitas memiliki serum besi, saturasi transferin, dan $M C V$ yang lebih rendah dibandingkan dengan individu normal. Penelitian tersebut juga mendapatkan bahwa kadar serum reseptor transferin tinggi pada subjek obesitas yang mengindikasi bahwa peningkatan lemak berhubungan dengan meningkatnya risiko defisiensi besi. Selain itu, subjek obesitasmengalami fase inflamasi yang ditandai dengan kadar feritin dan $C$-reactive protein yang meningkat. ${ }^{23}$ Penurunan kadar besi dalam darah akan menjadi penyebab anemia ditahap selanjutnya. ${ }^{6}$

Keterbatasan jumlah subjek dan penggunaan Food Frequency Questionnaire semikuantitatif sebagai metode pengukuran asupan besi menjadi keterbatasan penelitian ini. Metode pengukuran asupan besi ideal adalah menggunakan weighted food records yaitu dengan menimbang dan mengecek setiap kandungan makanan di laboratorium selama lebih dari tujuh hari. ${ }^{24}$ Peneliti tidak menggunakan weighted food records karena keterbatasan waktu dan sumber daya. Peneliti memilih $F F Q$ karena dapat memberikan hasil yang sebanding dengan metode ideal dan baik digunakan untuk menilai asupan gizi mikro seperti besi. ${ }^{16}$

\section{Simpulan}

Hasil penelitian ini menunjukkan asupan besi pada subjek laki-laki 62,5\% terkategori cukup dan 37,5\% terkategori kurang. Asupan besi pada subjek wanita 20\% terkategori cukup dan $80 \%$ terkategori kurang. Kadar hemoglobin subjek pria normal dan $20 \%$ wanita mengalami anemia. Semua subjek pria memiliki indeks sel darah merah normal yaitu normositik normokrom. Pada wanita, 40\% subjek memiliki indeks sel darah merah mikrositik hipokrom.

Saran untuk penelitian selanjutnya adalah melibatkan lebih banyak subjek, serta melengkapi data dengan beberapa pemeriksaan terkait, misalnya kadar besi dalam darah. Besi yang dikonsumsi akan dimetabolisme lagi di dalam tubuh dan dipengaruhi banyak faktor. Kandungan vitamin $\mathrm{C}$ menjadi faktor yang dapat meningkatkan absorpsi besi, kandungan phytate dapat menurunkan absorpsi besi atau kebutuhan besi dalam tubuh seseorang. ${ }^{7}$ Pemeriksaan kadar besi dalam darah seperti ferritin lebih baik untuk mengetahui kadar besi dalam tubuh.

\section{Daftar Pustaka}

1. World Health Organization [database on the Internet], Overweight and Obesity. - [cited 201730 June]. Available from: http://www.who.int/mediacentre/factsheets/fs311/en/

2. World Heatlh Organization. Obesity: Preventing and Managing the Global Epidemic. Geneva: 2000. 


\section{Research Article}

3. Kussoy K, Fatimawali, Kepel B. Prevalensi Obesitas Pada Remaja di Kabupaten Minahasa. Jurnal eBm. 2013;1(2):981-5.

4. Badan Penelitian dan Pengembangan Kesehatan Kementerian Kesehatan Republik Indonesia. Riset Kesehatan Dasar. Kementerian Kesehatan Republik Indonesia. Jakarta; 2013.h. 2222.

5. Duggan C, Watkins JB, Koletzko B. Nutrition in Pediatrics. 5th ed.Shelton: Pmph; 2016. p. 442-7.

6. Miller JL. Iron Deficiency Anemia: A Common and Curable Disease. Cold Spring Harb Perspect Med. 2013;3(7):10-23.

7. Harmening D. Clinical Hematology and Fundamentals of Hemostasis. 5th ed.Philadelphia: F.A. Davis; 2009. p. 118-32.

8. Pinhas-Hamiel O, Newfield RS, Koren I, Agmon A, Lilos P, Philip M. Greater Prevalence of Iron Deficiency in Overweight and Obese Children and Adolescents. Int J Obese. 2003;27(3):416-8.

9. Sujatha R, Reshma. Occurrence of Iron Deficiency Anemia Between Over Weight and Normal Weight Adolescents in Selected Schools in Udupi District. Nitte University Journal of Health Science. 2014;4(4):33-8.

10. Cheng HL, Bryant CE, Rooney KB, Steinbeck KS, Griffin HJ, Petocz P, et al. Iron, Hepcidin and Inflammatory Status of Young Healthy Overweight and Obese Women in Australia. PLoS ONE. 2013;8(7):e68675.

11. Ganasegeran K, Al-Dubai SA, Qureshi AM, et al. Social and Psychological Factors Affecting Eating Habits Among University Students in a Malaysian Medical School: A Cross-sectional Study. Nutr J. 2012;11(1):4854.

12. Sajwani RA, Shoukat S, Raza R. Knowledge and Practice of Healthy Lifestyle and Dietary Habits in Medical and Non-medical Students of Karachi, Pakistan. J Pak Med Assoc. 2009;59(9):650-5.

13. Mikolajczyk RT, El Ansari W, Maxwell AE, et al. Food Consumption Frequency and Perceived Stress and Depressive Symptoms among Students in Three European Countries. Nutr J. 2009;8(1):31-8.

14. Tesfaye M, Yemane T, Adisu W, Asres Y, Gedefaw L. Anemia and Iron Deficiency among School Adolescents: Burden, Severity, and Determinant Factors in Southwest Ethiopia. Adolesc Health Med Ther. 2015;6(1):189-96.

15. Amelia S. Permenkes Tentang Angka Kecukupan Gizi. 2014 [cited 201730 Juni]; Available from: http://gizi.depkes.go.id/permenkes-tentang-angka-kecukupan-gizi.

16. Fitri N, Jafar N, Indriasari R. Studi Validasi Semi-Quatitative Food Frequency Questionnaire dengan Food Recall 24 Jam pada Asupan Zat Gizi Mikro Remaja di SMA Islam Athira Makassar [repository]. Makassar: Universitas Hasanuddin; 2013.

17. Martin LJ. RBC Indices. 2016 [cited $2017 \quad 30$ Juni]; Available from: https://medlineplus.gov/ency/article/003648.htm.

18. Sekhar DL, Murray-Kolb LE, Wang L, Kunselman AR, Paul IM. Adolescent Anemia Screening During Ambulatory Pediatric Visits in the United States. J Community Health. 2015;40(2):331-8.

19. Sekhar DL, Murray-Kolb LE, Kunselman AR, Weisman CS, Paul IM. Association between menarche and iron deficiency in non-anemic young women. PLoS ONE. 2017;12(5):e0177183.

20. Urrechaga E, Hoffmann JJML, Izquierdo S, Escanero JF. Differential Diagnosis of Microcytic Anemia: the Role of Microcytic and Hypochromic Erythrocytes. Int J Lab Hematol. 2015;37(3):334-40.

21. Ward D, Kaplan J. Ferroportin-Mediated Iron Transport: Expression and Regulation. Biochem Biophys Acta. 2013;1823(9):1426-33.

22. Cepeda-Lopez AC, Osendarp SJ, Melse-Boonstra A, Aeberli I, Gonzalez-Salazar F, Feskens E, et al. Sharply Higher Rates of Iron Deficiency in Obese Mexican Women and Children are Predicted by Obesity-Related Inflammation Rather Than by Differences in Dietary Iron Intake. Am J Clin Nutr. 2011;93(5):975-83.

23. Yanoff LB, Menzie CM, Denkinger B, Sebring NG, McHugh T, Remaley AT, et al. Inflammation and Iron Deficiency in the Hypoferremia of Obesity. Int J Obese. 2007;31(9):1412-9.

24. Liu L, Wang PP, Roebothan B, Ryan A, Tucker CS, Colbourne J, et al.Assessing the Validity of a SelfAdministered Food-Frequency Questionnaire (FFQ ) in the Adult Population of Newfoundland and Labrador, Canada. Nutr J. 2013;12(49):1-9. 